demand. He stressed the importance of the appointments officers of the universities and suggested that they deserve better support. As regards quality, more first-class graduates are required and, particularly in the average man, an improvement in quality is desirable.

Sir Edward Herbert's address in some respects overlapped that of Lord Hives. He too agreed that industry recognizes that the first function of a university must always be that single-minded pursuit of learning and continual advance of knowledge which are essential to the existence and growth of a civilized society. The value of a university graduate in industry, or in any other walk of life, lies in the trained and flexible mind which the three or four years of mental discipline may be expected to produce. It does not lie in the possession of any particular body of knowledge, and Sir Edward suggested, in considering what qualities industry looks for in its recruits from the universities, that we should look not at the graduate starting his first job, but at the man he hopes to become at thirty-five or forty on the threshold of major responsibilities. His future would then turn, not on his specialized knowledge but on his capacity to assume responsibility.

Accordingly, Sir Edward thought, industry would seek for such future leaders a combination of threc main categories of ability. First, the ability to equip oneself thoroughly with expert knowledge of the particular aspect of the business in which one is engaged ; this provides the basis of genuine authority. Second is the ability to relate this specialist function to the conduct of the business as a whole, including not merely the problems of the industry but also of the community which that industry serves. The third is the ability to sustain the moral burden of responsibility. Sir Edward made no suggestion as to what formal part the university can hope to take in preparing a man for this last responsibility; but a university should, he thought, be able to foster a lasting regard for other human beings, and it should strive to instil the conception of duty and service. All who hold authority in a community should be constantly aware of the human implications of the decisions they have to make from day to day, but Sir Edward believed that professional training in business administration and management should come some time after the degree course, and not form part of it. Finally, he stressed the immense value of a friendly understanding between the universities and industry and the need for industry to become much more imaginatively alive to its own opportunities and achievements.

The importance of co-operation betweon the universities and industry was also stressed by Prof. Pope, who pointed out that, with the adequate financial assistance now available, practically all able boys and girls from the grammar and secondary schools in Britain are proceeding to a university ; as a consequence, the direct entry into industry from schools has suffered considerably, and this is a problem which has been considered more particularly at a subsequent conference of the Federation of British Industries held last October. Apart from the professional qualifications, Prof. Pope maintained that a university education should discipline a person to be intellectually honest and to be capable of a balanced view of issues as they arrive.

While Dr. Wells also stressed the need for more and closer personal relations between industry and the universities, particularly on the social science side, his address was largely a plea for specific assistance from industry in providing material for economic studies. First, he said, more opportunities are needed for studying the organization of firms and for investigating their problems at first hand. Secondly, there is the desirability of having access to business records, particularly old historical records ; and thirdly, the assistance of industry in developing the method of teaching based on case study. Fourthly, it is desirable to know more about the associations of the business world, such as the Federation of British Industries, the British Employers' Confederation and some of the more important sectional organizations. Far more, he said, is known of the trades union movement than of its counterpart on the employers' side.

\section{SOUTH AFRICAN ASSOCIATION FOR THE ADVANCEMENT OF SCIENCE}

\section{FIFTIETH ANNIVERSARY}

$\mathrm{W}$ HEN the South African Association for the Advancement of Science met last year, during July 7-12, in the buildings of the University of Cape Town, it was to celebrate the golden jubilee of its foundation, for, though the date did not exactly coincide with fifty years, the occasion was fitting in that it was in Cape Town on September 12, 1901, when the constitution of the Association was drawn up, and on April 27, 1903, also in Cape Town, when the first annual meeting was held. The meeting last year, which was under the presidency of Dr. B. F. J. Schonland, of the Bernard Price Institute of Geophysical Research, Johannesburg, was marked by the invitation of the following distinguished guests from overseas : Sir Lawrence Bragg (Cambridge) and Sir Edward Salisbury (Kew Gardens); Prof. L. E. J. Brouwer (Amsterdam) and Prof. J. H. Oort (Leyden); Canon G. Lemaître (Louvain) and Prof. G. Magnel (Ghent); Dr. H. Vallois (Paris); and Prof. A. da Silva Rego (Lisbon). The official representatives of other bodies were as follows: for the sister Associations in Australia and New Zealand and in the United States, Sir Kerr Grant, the Australian physicist, and Dr. J. D. J. Hofmeyr, of Pretoria, respectively ; for the Royal Society of South Africa, the oldest scientific society in the country (which, incidentally, was celebrating its seventy-fifth anniversary), Prof. R. W. James, of the University of Cape Town; and for the Suid-Afrikaanse Akademie vir Wetenskap, Dr. T. E. W. Schumann, director of the Weather Bureau of the Union of South Africa.

The activities of the meeting are recorded in the October-November issue of the Association's journal, the South African Journal of Science, and in this issue are published a brief description of the meeting, Dr. Schonland's presidential address and the texts of eleven papers, included in which are those of overseas visitors-namely, Dr. Vallois, Canon Lemaître, Prof. Oort, Prof. Rego, Sir Lawrence Bragg, Sir Edward Salisbury and Prof. Brouwer.

Dr. Schonland began his address by outlining the inception of the Association under the presidency of Sir David Gill, then H.M. Astronomer at the Cape, and showed how the early enthusiasm of the first meeting, at which $\mathbf{7 0 3}$ full members and 36 associates attended, led to a membership of 1,322 in 1906 , 
which has never been since surpassed. Dr. Schonland expressed disappointment that the membership in recent years has been but a little more than a thousand, for South Africa has expanded enormously since 1906 and with this expansion the need for, and potential value of, such a body as the Association. The general aims of the Association have not changed at all with the passing of years: "We exist," he said, "primarily to create and foster a scientific fraternity in South Africa, not to publish original work. We exist to provide a common meeting-ground for South African scientists and a forum for general discussion of the problems of this country from the scientific angle." He defended the use of Afrikaans by those who preferred it, for "we were intended by our founders to be parochial, and we should pride ourselves on being parochial. I would suggest that if we try to be anything else we will have mistaken our real aim".

Having thus firmly and, most people would agree, wisely placed the Association in its proper perspective, Dr. Schonland went on to make some concrete suggestions. The South African Journal of Science should have a series of semi-popular articles reviewing and surveying the new ideas of science and so bridge the gap between those who teach and do advanced research work and those who pay for it. This, he thought, is the proper function of the Journal, and it is but one aspect of the Association's duty, as representative of all sections of scientific opinion in South Africa, "to take a stronger, a more continuing and a more active interest in all scientific developments, national and university, in South Africa and to study carefully what is being done in other countries".

Besides his plea that the Association needs to form a standing committee to watch over scientific education in schools, Dr. Schonland suggested that the Association might consider taking a part in the formation of a body on the lines of the British Parliamentary and Scientific Committee and also help in the creation of better facilities for advanced. research in South Africa. On this last-named point, he cited the instances of the National University in Canberra and the Institute for Advanced Studies in Dublin, but he made the interesting suggestion that a more acceptable solution might be the creation of a number of specialized institutes for advanced study, attached to and forming part of those universities which for one reason or another are best suited for them.

\section{BASIS OF TECHNICAL EDUCATION}

CENERAL education to-day should be planned $\checkmark$ so as to enable the ordinary citizen to adapt himself to the needs of technological society and to understand what is happening and what is required of him. This was the theme of an international conference convened by the United Nations Educational, Cultural and Scientific Organization at Unesco House in June 1950*.

Broadly, the Conference found that organized social foresight is essential to enable the educational system of a country to prepare children for the type of life and work they are likely to encounter, and that a substantial development of technical education

* Education in a Technological Society : a Preliminary Inter national Survey of the Nature and Efficacy of Technical Education (Tensions and Technology Series.) Pp. 76. (Paris: Unesco; London :
H.M.S.O., 1952.) 200 francs ; 48.; 75 cents. is required at all levels : at present it is wholly inadequate for future needs, while the practical content of general education is also inadequate for the needs of future citizens of a technological society. The cultural content of technical education is also generally inadequate; technical education requires special consideration, and training for adaptability is an outstanding requirement in an age of ultra-rapid technological change. The education of women and girls also demands particular attention in view of their dual role as workers and home-makers, and improved administrative arrangements are essential if education is to fulfil its true function in such a society.

The report does not suggest that all these propositions apply equally to every country, though the Conference considered that, so far as its knowledge extended, they are generally valid for the world as a whole. The stress is laid on the need for adapting technology to man, not man to technology. The questions formulated in this report-and which merit attention in current discussions on the expansion of both technical and technological education in Great Britain-are raised in the belief that mastery of the machine by man is not an end in itself : it is a means to the development of man and of the whole society.

The distinction between technician and technologist is not always kept clear in this report, particularly in the chapter on the content of technical education. Nevertheless, the report directs attention to some fundamental issues which no sound policy for either type of education can disregard. In both fields it must be recognized that we are concerned not simply with the efficiency of production, but also with the fundamental attitude which the men and women of to-morrow will adopt in facing the problems of a technological society. Both, too, in seeking to foster flexibility, must recognize that flexibility is determined not only by education and training but also by social, economic and technical conditions; and the administrative measures required to ensure that education becomes more adapted to the needs of a changing technological society are themselves likely to be most effective when they are informal and varied rather than concentrated and uniform. The administrator, no less than the teacher and student, has need of frequent opportunities of contact with the industrial world, and requires experience of the difficulties and problems created by technological development in society; just as the teacher and student should keep abreast of developments in research and of practical applications in industry.

\section{GENETICAL IMPLICATIONS OF THE STRUCTURE OF DEOXYRIBONUCLEIC ACID}

\author{
By J. D. WATSON and F. H. C. CRICK
}

Medical Research Council Unit for the Study of the Molecular Structure of Biological Systems, Cavendish Laboratory, Cambridge

$T$ HE importance of deoxyribonucleic acid (DNA) within living cells is undisputed. It is found in all dividing cells, largely if not entirely in the nucleus, where it is an essential constituent of the chromosomes. Many lines of evidence indicate that it is the carrier of a part of (if not all) the genetic specificity of the chromosomes and thus of the gene itself. 